\title{
Did Socially Responsible Investment Create the Added Value for the Company? A study Case in the Company of Phosphate of Gafsa
}

\author{
Amara Tijani $^{1}$ and Fakhfakh Hamadi ${ }^{2}$ \\ ${ }^{1}$ Institut Supérieur d’Administration des Entreprises, Université de Gafsa, Tunisie \\ ${ }^{2}$ Faculté des Sciences Economiques et de Gestion, Université de Sfax, Tunisie
}

\begin{abstract}
Undertake in a vision of social ethics, implies that the company must behave like a responsible citizen. For this propose, the company is now responsible for negative effects of its activities. That mean, the company must actively contribute to minimizing the risks by engaging the environmental projects. While these investments are a threat to performance for some companies, others consider them a competitive factor and a source of value creation.

Through this study, the authors will demonstrate, through a case study, that socially responsible investing can be, contrary to what most entrepreneurs think, a lever of value creation for the company. Thus, the first part will discuss the concepts of socially responsible investments and the related objectives. The second part will present the calculations related to the environmental investments and determine the added value of environmental protection while discussing the results emerging from the case study of the Company of Phosphate of Gafsa.
\end{abstract}

Keywords: Social responsibility, Value creation, protection of the environment, responsible investment.

\section{Introduction}

With the development of research in the field of ecology, society is becoming increasingly aware of the potential impact of business activities on the environment. For McWilliams et al (2001), it is, thus, necessary that the corporate polluters take responsibility for the externalities borne by stakeholders. This action helps to bring business operations into a economic and social benefit to all stakeholders.

This orientation helps to develop and expand social and environmental responsibilities of corporate polluters. According to Delphine (2008), the responsible company is one that reflects the consequences of its actions on itself and its environment. The corporate responsibility becomes an aspect to achieve commercial success by honouring ethical values, respect for individuals, communities and the environment. A socially responsible company is about not only satisfying the applicable legal requirements, but also, investing more in human capital, environment and relationships with stakeholders.

Copyright (C) 2012 Amara Tijani and Fakhfakh Hamadi. This is an open access article distributed under the Creative Commons Attribution License unported 3.0, which permits unrestricted use, distribution, and reproduction in any medium, provided that original work is properly cited. Contact author: Amara Tijani Email: tijani_amara@yahoo.fr 
The socially and economically sustainable company implies that it must behave as a responsible citizen, not only for realization of profits, but for its social duty as well. This entails rights but also duties. In other words, accountability to the society.

Gradually, companies direct their concerns towards minimizing the adverse effects on the environment by controlling the environmental costs generated by their activities and supported by the community. For André (1999), the majority of businesses consider that environmental protection is a competitive factor.

Based on these principles, and in response to increasing pressure to improve its environmental performance, the Company of Phosphate of Gafsa was the first to develop a set of principles designed to improve its practices regarding the manufacture of its products. In the first part of this paper, the authors present the theoretical concepts related to responsible investment and then proceed to calculate the investments incurred by this company and determine the added value of environmental protection.

\section{Socially Responsible Investment: Concepts and Prospects for Creating Value.}

\section{Concepts and Objectives}

According to Guyot (2004), the Socially Responsible investment (SRI) encompasses all aspects that integrate extra-financial criteria in decisions. The extra-financial performance of the company is based in part on evidence that a cooperative company would have more shareholder value. Some arguments address this context. For Charreaux et al (1998), adoption of social practices increases shareholder value of the company. This helps enhance the image of the company among stakeholders.

According to Roux (2005), socially responsible investment is a part of ethical finance. In this perspective, Erwan (2007) indicates that the financial performance of the company has become relatively greater because of social investment. In the same context, Postel et al (2006) confirm through their studies on the relationship of corporate social responsibility and socially responsible investment, the positive correlation between the two variables. According to Pesqueux (2002), socially responsible funds run by selecting companies based on their performance in terms of sustainable development.

The most recent socially responsible investment appeared in 1980. This form states that the investment taking into account social and environmental practices could have positive impacts on business performance. The concept of sustainable development appeared with Jacques (2002). Taking into consideration criteria related to the environmental management, the authors can identify elements that impact on the long-term value, productivity and competitiveness of the company.

Responsible investment reflects the social behaviour of the company vis-à-vis the community. According to Mathews (1993), social responsibility can have three distinct components:

- It may derive from the unintended consequences of related business activity;

- It can affect the quality of life within and outside the company;

- It can take up a civic consciousness on the part of the contractor.

Companies are, according to Carroll (1979), vital centres of decision and power. Their actions affect the lives of partners in many areas. Based on these principles, Mohamed et al (2009) confirm that companies are responsible for their actions in a wider sphere than the mere economic sphere. The objectives of socially responsible investment are not limited to generate profit in a capitalist economic system but also to satisfy 
the community in response to stakeholder expectations. Practically, socially responsible funds are classified into three categories: negative, positive and best-in-class. The most important approach is the positive approach. This approach aims to encourage companies considered the most socially responsible. In this context, companies preferred are those that have developed technologies called "environmental" or "clean". According to Davis et al (1991), clean technologies are the new industrial processes or changes in existing processes, to reduce the environmental impact of productive activities, including reducing energy consumption and raw materials. Clean technologies according to Cagnon et al (2005) allow reducing pollution at source and even preventing it. The term source reduction means any practice which reduces the amount of hazardous substances or pollutants. This, in effect reduces the danger to society and the environment.

\section{The Different Forms of Socially Responsible Investment}

Several concepts can be attributed to socially responsible investment for example, the socially responsible fund or the sustainable development funds or even ethical funds. All these aspects are related specifically to compliance with certain requirements of environmental protection, social equity and corporate governance. Practically, Loiselet (2000) notes that there are three main approaches related to this phenomenon: the approach best-in-class, the filtering approach and the shareholder activism approach.

The approach best-in-class is based on the selection of companies that perform better financial performance. This is practical without excluding or privileging any environmental and social sector. This approach seeks to support social responsibility in business by promoting, in each sector, the most virtuous companies.

The negative filtering approach is based on the exclusion of certain companies, claiming they are not "ethical". However, the filtering approach focuses on the positive business sectors due to their charge promoter in sustainable development.

The approach of shareholder activism is one in which investors have the desire to change corporate policy by becoming more involved in business strategies. This is possible by exercising pressure on leaders to guide them especially in the way to the social responsibility. The practice of this approach begins first with a simple dialogue with leaders. It can even reach the application of the voting rights and proposing in general meetings of shareholders a number of solutions to integrate the notion of responsibility in the corporate strategy of the company.

\section{The Socially Responsible Investment and the Value Creation}

Generally speaking, the financial factor influences the behavior of the company. Socially Responsible Investing, which integrates the criteria of social and environmental into the traditional financial, is growing rapidly in recent years. Skinner (2001) notes that, the socially responsible investing, is a practice that incorporates social and environmental concerns into investment decisions.

According to Mackenzie et al (1999), most studies show that a socially responsible investor believes that this investment makes a difference to the individual by meeting her social conscience. Lewis (2001) emphasizes that greater awareness of the influence of industry indicates that while the impact is not limited to the individual level, big changes are not imminent. However, socially responsible investors want to feel they belong to a new sustainable movement. Socially responsible investing has a fundamental impact on two key concepts of the market economy. First, this investment is a lever of value creation for the company. Indeed, as pointed out by Capron et al (2005), SRI is a fundamental factor in performance, innovation and a lever for 
creating value in the medium and long term. Accordingly, the analysis of existing products shows that socially responsible companies are also gaining in overall performance.

In the same context, Seyrino (2008) notes that effective protection of the environment actually leads to reactions from the stakeholders who are indeed a source of value creation for the contemporary company. Bearing this in mind, it can be seen that the value created can be either financial or intangible. Companies are being called to trust this type of value created. The socially responsible investment is actively involved in changing the relationship between the company and its shareholders. On the one hand, this investment invites the shareholders to change corporate behaviour by encouraging "shareholder activism" and, on the other hand, the company encourages accountability to its shareholders, not only on its economic performance but also in respect of its entire business and the environmental and social impacts it can generate.

Several researchers (Aiche, 2000; Dubingeon, 2005) confirm the existence of non-financial dimension to the utility function. Hence, socially responsible investors are interested in social reputation, the need for decisionmaking autonomy and reward for their private actions. This idea is confirmed by an empirical study which states that, the behaviour of socially responsible investors is relatively sensitive for losses and gains. Thus, the economic cost of under-performance does not determine alone the investment decision (Lewis et al2000a, Lewis et al 2001). These studies suggest that investors are reluctant to be characterized as economically rational.

The first ISR has appeared in 1990 with the economic theory taking into account the social and environmental fields. Investments are primarily intended to create value for shareholders. According to this perspective, SRI differs from conventional finance, not in its aims, but in taking into account extra- financial elements in its investment process. Within this framework, many companies take into consideration the interests of stakeholders and contribute to maximizing their long-term social interests. In this perspective, the integration of non-financial items such as environmental and governance factors in addition to the traditional financial criteria in the evaluation process undertaken by SRI can identify with the most successful mechanisms for creating shareholder value.

Cullis et al (1992) noted that adoption of social practices increases shareholder value of the company. However, development of green funds has emerged in the 1990s. This is means investing not only in non-polluting activities but also in privileged companies adopting production techniques that have positive impacts on the environment.

\section{Quantifying of Environmental Investments and Added Value}

\section{The Study Background}

Integrating the environmental dimension in the company's strategy involves taking it into account at all levels. In this perspective, Caroline (2005) notes that investments made for environmental protection, and the related financial information, are particularly needed by the stakeholders for decision making.

The problem of the environment in Tunisia arises in a very acute fashion for several reasons including resource scarcity, population growth and pollution.

The Tunisian natural resources seem to be devoid such as rivers and lakes. This is indeed, the consequence of a massive consumption of water by industry and in particular the production of phosphate and sulfuric acid. This situation has created a water shortage that is causing a process of desertification. Thus, the phenomenon of soil erosion has contributed to the degradation of fertile land. 
The growth of population is the main cause of the urbanization. In consequence, the urbanization becomes a major source of pollution. In addition, the Tunisian industrial companies, particularly those operating in the chemical sector, contribute to the increase of air pollution that has generated several diseases in the short and long term including cancer.

Although, the Tunisian State provides grants to businesses that contribute to reducing its negative effects on the environment, the inclusion of an effective policy for the protection of the environment in corporate strategy remains voluntary. In addition to this factor, the relatively low pressure of the community on the polluters encourages industrial companies to continue pollution production. Currently, the community privileges employability to a clean environment. This is justified due to the high rate of unemployment in Tunisia.

To judge the effectiveness of environmental investment in the industrial sector in Tunisia, a thorough case study was conducted in an industrial enterprise in Tunisia. It is through this empirical study that the researchers can identify and analyze the value of the socially responsible investment engaged by the Company of the Phosphate of Gafsa.

Under this section, the researchers will first present their case study namely the Company of Phosphate of Gafsa and a description of its production process and the impacts of its activities on the environment. We then present the details of calculations of the investments engaged for environmental protection. These investments have contributed in creating the added value for the Company, and on the other hand, in protecting the internal and external environment.

\section{Presentation of the Company of Phosphates of Gafsa (CPG)}

With a century of experience in operating and marketing of Tunisian phosphates, the
CPG is among the largest producers of phosphates in the world. It ranked the fifth largest company worldwide in 2010.

The CPG exploits ten quarries spread over five mining centers. At the geological scale, all producing fields are back to the Eocene. The surface mining of phosphates Tunisia has made significant gains in the cost of production which has improved productivity. The company currently operates seven open pits and one underground mine. Annual production is currently 8 million tons of phosphates.

Phosphates merchants fall into two main categories based on the title of P205. Quality $65-68 \%$ BPL is mainly for the production of phosphoric acid and fertilizers while the quality $60-62 \%$ BPL is used for direct application. Approximately $80 \%$ of domestic production of phosphate is delivered to local units of chemical transformation of the Tunisian Group. The remainder is sent to the port of Sfax for export. The CPG markets its products in over twenty countries around the world both for processing and direct application.

\section{The Stages of Phosphate Production}

The phosphate mining is in open air. After mining, the phosphate is transferred into processing plants. However, treatment of phosphate depends on its content of GLP (Good Phosphate of Lime). It is classified into four categories:

- The high phosphate content (HT)

- The average phosphate content (MT)

- The low phosphate content (BT)

The first two categories of phosphates are considered marketable products without enrichment. By contrast, phosphates, BT and TBT must undergo enrichment before being used in the manufacture of marketability. 
The latter can undergo different modes of treatment such as washing in laundries, dry enrichment and flotation. Washing of phosphates is a transaction consisting of several phases including the preparation of mechanical separation and treatment that aims to increase the content of P205. The production process of dried and filtered phosphate can be summarized as follows:

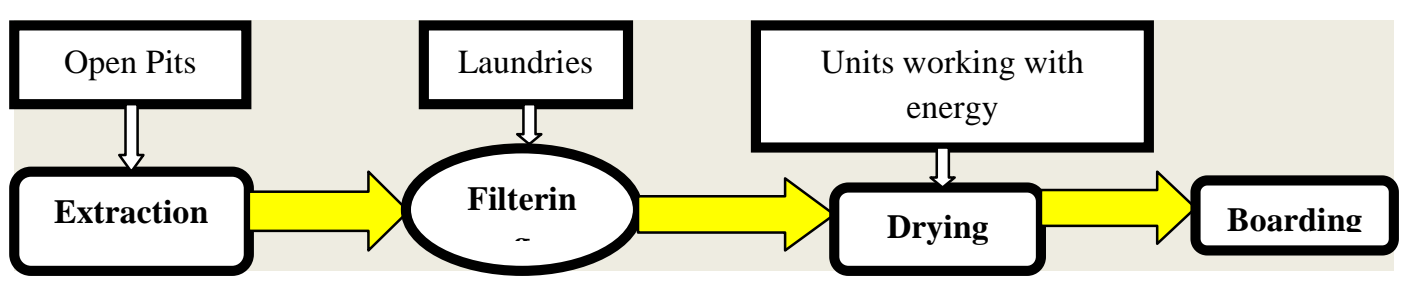

Figure (1) The Old Processes of Production

The separation of the grains is fed by 5 tonnes of water for every tonne of phosphate. However, of those five tons, 3.65 tons are recycled; 0.15 tons go with phosphate product. As a result, 1.2 tons are lost. Thus, the production of 8 million tonnes per year of commercial phosphate, consumes about 10.5 million m3. Table (01) summarizes the average water consumption by all of the laundries of Gafsa mining area.

Table (01) Annual Consumption of Water

\begin{tabular}{|l|c|}
\hline Sector of production & $\begin{array}{c}\text { Consumption : annual } \\
\text { average in } \mathbf{1 0 0 0} \mathbf{~ m}^{\mathbf{3}}\end{array}$ \\
\hline M'Dhilla & 3639 \\
\hline Metlaoui & 8700 \\
\hline Moulares & 2032 \\
\hline Redeyef & 2077 \\
\hline Total & 16502 \\
\hline
\end{tabular}

Source: Cost Reports of the Company

Water used for the treatment of phosphate is currently provided by the very deep surveys. According to the experts of the CPG, the company uses the water of the Continental spacer which is about 1000 meters depth. The water of the continental fossil interlayer is a layer. It is therefore, according to them, not renewable. Until 2005, the CPG lost about 6 million $\mathrm{m} 3$ of water.

\section{The Impact of Phosphate Activities on the Environment}

Phosphate activities are the cause of many environmental challenges in quarries and processing units. According to Jarvis et al (1994), phosphate rocks contain many metal elements, some of them, are considered as impurities and therefore have negative impacts on the environment. Gnandi et al (2006) emphasize in their studies dealing with the environmental impacts of mining and processing of phosphates, that many diseases such as dental fluorosis in children are strongly linked to the presence of fluorine in phosphate rock.

In addition, Giraud (1983) confirms that the mining industry is, by definition extremely polluting. The sources of pollution are essentially from discharges of solid, liquid and gas. The mining industry is known for its consumer space character. After a while, all 
the wildlife (animal and plant) in the vicinity of the mining region disappear.

In terms of air quality, any mining operation has the option of increasing the dust content of the ambient air. This causes negative effects on the respiratory system of humans. Studies of several researchers (Pope and al. 2002; McDonnell and al. 2000), have shown that fine particles of phosphate in the air contribute actively to appearance of cancer in young adults and in the coalfields. Lipfert et al (2000) go further by demonstrating that the phosphate is the main cause of fatal cancer cases. Other studies in Germany (Heinrich et al 1999, 2000 and 2002) also confirmed that the fine particles of phosphate are the main causes of bronchitis and asthma in children in particular.

The treatment operation of wastewater requires huge amounts of water which, after being charged with sterile and harmful materials, are poured into the wades of the region. In addition, these waters flow without fuelling deep aquifers as they are made of impermeable clay. They also have negative impacts on the environment of the region such as the deterioration of agricultural land, animals and consequently human health. Narasiah et al (1988) stress the need to take precautions to ensure that the maximum concentrations of phosphates should not exceed the limits prescribed.

To cure these shortcomings, the CPG has taken preventive measures to reduce the negative effects of these activities on the surrounding environment. The completed project has been classified in environmental category, details of which will be released and presented in the following section.

\section{Objectives and Formulation of Storage Tanks for Discharges}

\section{Objectives}

The specific objective of the project selected and produced by the CPG is to reduce the harmful effects of mining and production of phosphates on the environment. This helps to:

- Control the impact of mining on the natural environment;

- Execute safe operating conditions for staff;

- Improve the quality of life of the region;

- Protect agricultural land;

- Preserve the groundwater in the region;

- Improve an effective and responsible management of water through the design and implementation of conservation measures;

- Improve the environmental performance of the CPG by contributing to the creation of Added value to the company.

\section{Formulation}

The draft Waste Management of the CPG is an important initiative to improve the quality of the environment. This project allows also the strengthening of the national management of water resources and a solution of water production in place of water wells. Storage of waste in tanks for containment can, indeed, allow the use of a new water source through unconventional methods by the Company. (Recovering and recycling the industrial water from sludge clay). It also reduces, land degradation and protect agricultural land, plants and quality of animal life.

Before this project, washing phosphates generates two types of releases:

- Corses rejects (particle size $>2 \mathrm{~mm}$ );

- Discharges (particle size $<71 \mu$ ).

Consequently, and with 10 operating phosphates laundries, the quantity released seems huge. The following table summarizes the amount paid into the water system: 
Table (02) Quantity of Water Rejected

\begin{tabular}{|l|c|c|}
\hline Laundries & Coarse reject (Tones) & ${\text { Mud in } \mathbf{~}^{\mathbf{3}}}$ \\
\hline Moulares & 380000 & 1650000 \\
\hline Rédeyef & 270000 & 1175000 \\
\hline Metlaoui & 1240000 & 5390000 \\
\hline M'dhilla & 610000 & 2655000 \\
\hline Total & 2500000 & 10870000 \\
\hline
\end{tabular}

Source: Cost Report of the Company

Faced with critical situation adversely affecting the environment, and as part of its policy of reducing the impact of its mining and industrial activities, the CPG has launched a responsible investment project. The solution adopted for the management of releases for laundries is to confine them in storage ponds. The choice of this solution relies on a series of environmental benefits, including:

- Absence of impact on the river system, there is no other watershed than itself;

- The rejected clay contributes to limiting the infiltration. Consequently, the infiltration rate becomes very low.
In additions to the tanks, the other components of the variant are pipes, electrical equipment and protective elements of the water recovery. All activities were carried out by the company.

The realization of storage tanks for releases of laundries has tweaked the production process of the company. The tanks have contributed not only recovering a large quantity of water, but also, a significant quantity of phosphates at low cost. The new process can be schematized as follows:

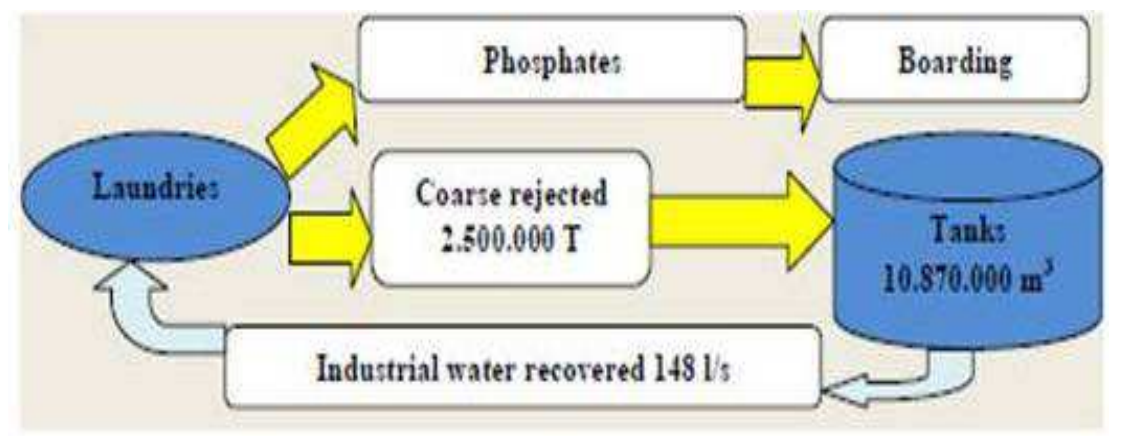

Figure (2) the New Process of Production 


\section{Costs of Tanks for Discharges}

The total cost at completion was 15.786 .000 Tunisian dinars. The funding of the total cost was done by the company. Details of costs per sector are as follows:

Table (03) Total Cost of Tanks

\begin{tabular}{|l|c|}
\hline Sectors & Cost (TD) \\
\hline Moulares & 2.249 .000 \\
\hline Redeyef & 3.284 .000 \\
\hline Metlaoui & 5.900 .000 \\
\hline M'Dhilla & 4.353 .000 \\
\hline Total & 15.786 .000 \\
\hline
\end{tabular}

Source: Financial Reports of the Company

Details of nature of loads during the five years of implementation of the tanks (20052009) are as follows:

Table (04) Load Détails (TD)

\begin{tabular}{|l|c|c|c|c|c|c|}
\hline Nature des charges & $\mathbf{2 0 0 5}$ & $\mathbf{2 0 0 6}$ & $\mathbf{2 0 0 7}$ & $\mathbf{2 0 0 8}$ & $\mathbf{2 0 0 9}$ & Total \\
\hline Staff cost's & 388240 & 250000 & 280000 & 815786 & 469518 & $\mathbf{2 2 0 3 5 4 4}$ \\
\hline Liquid fuels & 113580 & 74110 & 72759 & 868542 & 330232 & $\mathbf{1 4 5 9 2 2 3}$ \\
\hline Investment purchase & $\mathbf{7 2 6 6 0 5 2}$ & 0 & 0 & 0 & 0 & $\mathbf{0}$ \\
\hline Construction of work & 530000 & 310087 & 514641 & 467081 & 338640 & $\mathbf{2 1 6 0 4 4 9}$ \\
\hline Soare part & 50950 & 33246 & 67137 & 958551 & 341070 & $\mathbf{1 4 5 0 9 5 4}$ \\
\hline Amortis sement & 255000 & 253000 & 250000 & 243889 & 243889 & $\mathbf{1 2 4 5 7 7 8}$ \\
\hline Total & $\mathbf{8 6 0 3 8 2 2}$ & $\mathbf{9 2 0 4 4 3}$ & $\mathbf{1 1 8 4 5 3 7}$ & $\mathbf{3 3 5 3 8 4 9}$ & $\mathbf{1 7 2 3 3 4 9}$ & $\mathbf{1 5 7 8 6 0 0 0}$ \\
\hline & \multicolumn{7}{|l}{} \\
\hline
\end{tabular}

The project of protection used by the CPG avoids the environmental damage. It helps to prevent the pollution at its source. The establishment of this new technology has improved the quality of the environment and preserves, in particular, water resources. The exploitation of ground water is less with massive quantities of reclaimed water storage tanks for releases of different laundries of the CPG. In their study, Pretty et al (2001) identified a total of $£ 594.9$ million spent on environmental services (maintenance of landscapes, protection of sensitive areas, etc...)

\section{Recovery of Water and Phosphate from the Storage Tanks}

The investment made by the company for the protection of the environment during the 
2005-2009 years of study not only avoided the potential damage, but also generated an added value for the company. Based on the results generated, the quantities of water and phosphate recovered from storage tanks for releases laundries are very important. It is, thus, a significant quantity of water which represents about 30 to $35 \%$ of the average consumption of the company.

\section{The Quantities of Water Recovered}

The following table summarizes the quantity recovered during the study year 2005-2009.

Table (05) Quantity of Water Recovered

\begin{tabular}{|l|c|c|}
\hline Storage tanks & Water recovered $\mathbf{( m}^{3)}$ & $\begin{array}{l}\text { Water recovered } \\
\text { (litres) }\end{array}$ \\
\hline Moulares & 6.529 .800 & 1305960 \\
\hline Redeyef & 6.319 .000 & 1263800 \\
\hline Metlaoui & 8.500 .200 & 1700040 \\
\hline M'dhilla & 9.755 .000 & 1951000 \\
\hline Total secteurs & 31.104 .000 & 6220800 \\
\hline \multicolumn{2}{|c|}{ Source: Financial Reports of the Company }
\end{tabular}

According to the data provided, the realization of storage tanks has helped to recover and recycle at least $3.1104 .000 \mathrm{~m} 3$ of water at low cost for industrial use from 2005 to 2009 which constitutes $38 \%$ of the average consumption of the company. This allowed storing about 11 million $\mathrm{m} 3$ of waste for solid medium at a concentration of $230 \mathrm{~g}$ / l.

The committed investment has also contributed to:

- Limiting the overexploitation of the mining area;
- Defining the future strategy for managing water resources of the $\mathrm{CPG}$;

- The using of a non-conventional water resource.

\section{The Quantities of Recovered Phosphates}

During the years 2005-2009, the quantities of fine tailings stored in the storage tanks totalled $10870000 \mathrm{~m} 3$. With an average solid concentration of $230 \mathrm{~g} / \mathrm{l}$, the quantities of phosphate in tanks amounted to 2,500,000 tonnes. The following table shows the phosphates recovered:

Table (06) Quantity of Phosphate Recovered (2005-2009)

\begin{tabular}{|l|c|}
\hline Storage tanks & Total quantity recovered (tones) \\
\hline Moulares & 110 \\
\hline Redeyef & 115 \\
\hline Metlaoui & 140 \\
\hline M'dhilla & 135 \\
\hline Total & 500 \\
\hline
\end{tabular}

Source: Financial Reports of the Company

The results show that the company took advantage of a quantity of 500 tonnes of phosphate during the years of study. According to the experts of the company, this quantity is characterized with a high quality (high phosphate content including P205 is a quality of $65-68 \%$ ). This quantity is intended for direct production of the phosphoric acid and fertilizer plants in the Tunisian Chemical Group. 


\section{The Storage Tanks: Sources of Value Creation}

The researchers demonstrated that the investment made by the company on storage tanks for releases of laundries has not only avoided environmental damage, but also led to recovery of large quantities of high quality water and phosphate. The value of these quantities represents an added value for the phosphate company. The following table summarizes the value created due to environmental protection. Unit prices of phosphates are determined on the basis of the average during the years of the study. The cost of $\mathrm{m} 3$ of water drilling is $0.4 \mathrm{TD}$.

\section{Table (07) Total Added Value}

\begin{tabular}{|c|c|c|c|c|c|c|}
\hline Sectors & Phosphates T & Margin generated & Total TD & Water $1000 \mathrm{m3}$ & unit price & Total TD \\
\hline Moulares & 110 & $32 *$ & 3520 & 6529,8 & 0,4 & 2611920 \\
\hline Redeyef & 115 & 32 & 3680 & 6319 & 0,4 & 2527600 \\
\hline Metlaoui & 140 & 32 & 4480 & 8500,2 & 0,4 & 3400080 \\
\hline M'Dhilla & 135 & 32 & 4320 & 9755 & 0,4 & 3902000 \\
\hline Total & 500 & 32 & 16000 & 31104 & 0,4 & 12441600 \\
\hline \multicolumn{7}{|c|}{ Total Added value $=16000+12441600=12,457,600 \mathrm{TD}$} \\
\hline \multicolumn{7}{|c|}{ Source : made by researchers } \\
\hline
\end{tabular}

\section{Discussion}

By identifying the added value benefited from the investment project engaged by the company, the researchers enumerated several dangers related to the operating activities of phosphates without being able to move beyond qualitative census. However, this study allowed the researchers to point to the factor that limit the harmful effects on the environment is no longer negligible. The funds engaged by the company for environmental protection seems to be huge $(15786000$ DT, equivalent to $€$ $8,221,875.00)$. This reflects, in fact, the critical situation of the environment in the mining area of Gafsa.

In terms of human health, the consequences are very serious for the population. The researchers tried to see further studies carried out either by the company or by public authorities but, the lack of information still characterizes the behaviour of Tunisian businesses and public institutions. No studies were conducted in this area. Employability offered by the region's population generates limited consideration to the functions of environmental amenities. Priority is, indeed, attributed to the economic survival and not to the enjoyment of the environment.

In terms of environmental problems related to water, it is clear that before the implementation of storage tanks for releases laundries, no measure or action was taken to preserve and rationalize the exploitation of ground water. Soil quality was virtually destroyed, a complete deterioration of farmland resulted in turn.

\section{Conclusion}

The company of phosphate of Gafsa, through the investment incurred to mitigate the environmental consequences of its activities, has become responsible vis - à - vis the community and future generations. These expenses are, in fact, the cost of avoiding the probable degradation of the environment. 
In this study, the researchers demonstrated also that the consideration of environmental issues in production costs allows the company, on the one hand, to rationalize its consumption of natural resources in substantial savings and on the other hand, to respond to the demands of society in improving the quality of the environment.

The results of this study indicate that the selected project has not only limited degradation of soil and fertile land but also allowed the Company to recover 30 to $35 \%$ of its average water consumption. In addition, it contributed to the rationalization of the use of water in the laundry business and preserved the underground water in the mining area.

\section{References}

Aiche, (2000). (American Institute of Chemical Engineers). 'Total cost Assessment Methodology Internal Managerial Decision Making Tool,' Center for Waste Reduction Technologies, Arthur D. Little.

Andre, P. (1999). "L'évaluation des Impacts sur l'environnement - Processus Acteurs et Pratiques," Canada: Presses internationales polytechniques, p 416.

Capron, M. \& Quairel-Lanoizelee, F. (2005). 'Evaluer les Stratégies de Développement Durable des Entreprises : L'utopie Mobilisatrice de la Performance Globale,' Journée Développement Durable- AIMS - IAE d'Aix-en-Provence, pp.1-22.

Carroll, A. (1979). “A Three-Dimensional Conceptual Model of Corporate Social Performance," Academy of Management Review, ${ }^{\circ} 4$.

Chareaux, G. \& Desbrires, P. (1998). "Gouvernance des Entreprises: Valeur Partenariale Contre Valeur Actionnariale," Finance-Contrôle-stratégie, Vol.1, n², pp. 5788.
Davis, D., Morris, M. \& Allen, J. (1991). "Perceived Environmental Turbulence and its Effects on Selected Entrepreneurship, Marketing and Organizational Characteristics In Industrial Firms," Journal of the Academy of Marketing Science, vol. 19, n¹, pp. 43-51.

Delphine, G.- A. (2008). "La Perception du Dirigeant de PME de sa Responsabilité Sociale : Une Approche Par la Cartographie Cognitive," Thèse présentée à la Faculté des sciences économiques et sociales, université de fribourg, Suisse.

Gallez, C. \& Moroncici, A. (2003). le Manager et l'environnement, presse universitaire Romande Lausanne.

Gnandi, K., Tchangbedji, G., Killi, K., Baba, G. \& Abbe, K. (2006). "The Impact of Phosphate Mine Tailing on the Bioaccumulation of Heavy Metals in Marine Fish and Crustacean from the Coastal Zone at Togo," International Journal of Mine Water and Environment pp5662.

Guyot, J. (2004). 'L'investissement Socialement Responsable: La Recherché de Nouvelles Valeurs,' Asset Management Magazine, $\mathrm{N}^{\circ} 18$, août-septembre.

Harscoet, E. (2007). "Développement d'une Comptabilité Environnementale Orientée vers la Création de Valeur: L'application à un Investissement de Prévention des Pollutions," thèse de doctorat présentée à l'Ecole supérieure nationale d'Arts et Métiers, Chambéry France.

Herich, J., Holscher, B. \& Wichmann, H. E. (1999, 2000, 2002). "Decline of Ambient Air Pollution and Respiratory Symptoms in Children," Epidemol. 13, pp, 394-401.

Jacques- Jean Rosé (2002). 'Responsabilité Sociale de l'entreprise,' De Boeck, 1ère édition, Bruxelles, pp. 215- 238.

Jarvis, I. \& Burnett, W. C. (1994). 'Phosphorite Geochemistry: State-of-the-art and 
Environmental Concerns,' Ecologies Geol. Helv. Pp 643-657.

Lewis, A. (2001). "A Focus Group Study of the Motivation to Invest: 'Ethica/Green' and 'Ordinary' Investors Compared," Journal of Scio-Economics (July) 30(4), pp, 331-341.

Lewis, A. \& Mackenzie, C. (2000a). "Morals, Money, Ethical Investing and Economic Psychology," Human Relations (February) 53(2), pp, 179-191.

Loiselet, E. (2000). “L'investissement Socialement Responsible: Genèse, Methods et Enjeux," L'Economie Politique $N^{\circ} 7$, 3èmè trimestre.

Mackenzie, C. \& Lewis, A. (1999). "Morals and Markets: The Case of Ethical Investing," Business Ethics Quarterly 9(3) (July), 439452.

Mathews, M. R. (1993). Socially Responsible Accounting, London: Chapman Hall.

McWilliams, A. \& Siegel, D. (2001). "Corporate Social Responsibility: A Theory of the Firm Perspective," Academy of Management Review, vol. 26, $\mathrm{n}^{\circ} 1$, pp, 117127.

Mohamed, M. \& Sabah, T. (2009). "La Responsabilité Sociale de l'entreprise au Maroc : Une Étude Empirique Auprès des Petites et Moyennes Entreprises de la Région de Fès Boulemane," 11eme journées scientifiques de réseaux Entrepreneuriat AUF.
Narasiah, S., Shoiry, J. \& Morasse, C. (1988). "Effets Des variations des Températures Saisonnières sur les Modifications des Phosphates dans des Eaux Usées," Revue des sciences de l'eau, volume 1, numéro $4 \mathrm{pp}$, 305-320.

Pesqueux, Y. \& Biefnot, Y. (2002). L'éthique des Affaires, Paris Edition d'Organisation.

Pope, C. A., Burnett, R. T., Thun, M. J., Calle, E. E., Krewski, D., Ito, K. \& Thurston, G. D. (2002). "Lung Cancer, Cardiopulmonary Mortality, and Long-Terme Exposure to Fine Particulate Air Pollution," JAMA 287 pp, 1132-1141.

Postel, N., Rousseau, S. \& Sobel, R. (2006). “La Responsabilité Sociale et Environnementale des Entreprises," Economie appliquée LIX.

Pretty, J., Brett, C., Gee, D., Hine, R., Mason, C., Morison, M., Rayment, M., Van der Bijl, G. \& Dobbs, T. (2001). "Policy and Practice: Policy Challenges and Priorities for Internalizing the Externalities Costs," Journal of Environmental Planning and Management.

Roux, M. (2005). "Finance Éthique: Structures, Acteurs et Perspectives en France," Université Paris 13, CEPN, actes du 3ème congrès de l'ADERSE sur la responsabilité sociale de l'entreprise, Lyon.

Skinner, D. (2001). 'The Ethical Investor: A Guide to Socially Responsible Investing in Canada,' Toronto: Stoddart Publishing Co. Limited. 